\title{
MORPHOLOGICAL ANALYSIS OF BREAST AND THIGH MUSCLES IN DIFFERENT POSTNATAL AGES OF BROILER CHICKEN AND ITS CARCASS CHARACTERISTICS
}

\author{
M. S. Rahman* \\ Department of Anatomy and Histology, Faculty of Animal Science and Veterinary Medicine, Patuakhali \\ Science and Technology University, Bangladesh
}

\begin{abstract}
The aim of this experiment was to analyze the morphology of muscles and carcass quality Cobb-500 and Ross broiler chicken at different age, where the weight of live bird, carcass, major cut portions, lean and bone were measured. The average highest live weight at $\mathrm{D}_{35}$ was recorded as $1860.18 \pm 6.29 \mathrm{~g}$ in Cobb-500 and $1640.47 \pm 7.57 \mathrm{~g}$ in Ross broiler chicken. The average carcasses weights at $\mathrm{D}_{1}, \mathrm{D}_{7}, \mathrm{D}_{14}, \mathrm{D}_{21}, \mathrm{D}_{28}$ and $\mathrm{D}_{35}$ were recorded as $14.90 \pm 0.53 \mathrm{~g}, 27.85 \pm 0.30 \mathrm{~g}, 85.31 \pm 0.82 \mathrm{~g}$, $211.94 \pm 4.31 \mathrm{~g}, 618.36 \pm 0.92 \mathrm{~g}$ and $1289.05 \pm 5.39 \mathrm{~g}$ for Cobb-500 and in case of Ross strains $12.89 \pm 0.41 \mathrm{~g}, 25.83 \pm 0.38 \mathrm{~g}$, $82.09 \pm 0.35 \mathrm{~g}, 210.58 \pm 2.66 \mathrm{~g}, 565.55 \pm 2.41 \mathrm{~g}$ and $1133.80 \pm 3.51 \mathrm{~g}$ respectively. Highest dressing percentage was recorded at $\mathrm{D}_{35}$ which was $69.29 \pm 0.11 \mathrm{~g}$ in Cobb-500 and $69.12 \pm 0.12 \mathrm{~g}$ in Ross strains. The length, breadth, thickness and weight of pectoralis thoracis, supracoracoideus, iliotibialis lateralis and iliotibialis cranialis skeletal muscles were higher in Cobb-500 at every studied ages. Finally the experiment focused that Cobb-500 chicken is superior in terms of meat production for its unique skeletal muscle growth and carcass yield.
\end{abstract}

Key words: Morphology, Muscle, Carcass yield, Cobb-500, Ross chicken

\section{INTRODUTION}

New food sources and raw matters are reclaimed by the quick and uncontrolled increase of human population and of its higher life standards, as well. Meat is found on the top of food matters and poultry hybrids could provide high quality meat at large amount, at relatively low prices and short time and can be easily processed at a large variety of specific products (Teuşan et al., 2009). Broiler chicken is the cheapest and safest animal protein source which can efficiently and rapidly fulfill the shortage of protein requirements. The share of poultry in the animal protein component of the human diet is estimated to be 30 percent in 1995 (Huque, 1996). Small scale poultry farmers are the main producers of the poultry in Bangladesh. In an estimate on the production based on the year 1991, it was found that about 98 percent of chicken meat was produced by small scale farm holder (Huque and Stem, 1993). The International Food Policy Research Institute has estimated that by year 2015 broiler chicken will account for 40 percent of all animal protein (IFPRI, 2000). In spite of its potential, no research on muscular growth and carcass quality of broiler chicken grow satisfactory in Bangladesh. Most of the farmers rear Cobb-500 and Ross broiler chicks in their farms but they do not know which strain is more efficient in terms of muscular growth and carcass quality under the same management. The marketing of poultry has been greatly diversified with a significant increase in cut-up (parts) and processed products (Le Bihan et al., 2001). Consumers also like low fat meat to avoid health hazard. Demand for high quality cut-up (parts) and further processed convenience foods have changed its marketing practices (Wats and Kennet, 1995). For this reason breasts and broiler filets have become critical to processors (Young et al., 2001). The continuing effort made by breeders to produce broiler chickens with improved production traits necessitates continuing evaluation of the various broiler strains. Based on the age and strains characteristics, this study was performed aiming to determine the of meat yield and muscular growth in two commercial broiler strains named by Cobb-500 and Ross (a tetra linear hybrid produced by the British firm Ross Breeders (Adela Marcu et al., 2009) broiler chicken reared in small scale farming system in Bangladesh. The results of this study could give indications to small scale farm holders as to which strains of broiler chicken should be used for more profit, eventually resulting in an up scaling of the meat production.

*Corresponding e-mail address: saidur@pstu.ac.bd 


\section{S. Rahman}

\section{MATERIALS AND METHODS}

A total of 288 live birds of both strains were randomly collected from 16 different small scale broiler farm of Dinajpur, Rangpur and Nilphamari districts at $1^{\text {st }}, 7^{\text {th }}, 14^{\text {th }}, 21^{\text {st }}, 28^{\text {th }}$, and $35^{\text {th }}$ day of age. These biological samples were carried to the Anatomy and Histology laboratory of Hajee Mohammad Danesh Science and Technology University, Dinajpur. After recording the live weight the birds were allowed to slaughter through ventral neck cutting at about 3/4 diameter of the neck by using sharp knife. 5-6 minutes were allowed for proper bleeding. After removal of feather and skin subcutaneous fat was collected with the help of forceps and scalpel blade. Then eviscerated carcass was weighed. The major edible cut portions (breast, thighs and drumsticks) were separated and weighed. Total lean and total bone were collected and measured. The length, breadth, thickness and weight of $m$. pectoralis thoracis and $m$. supracoracoideus from breast, $m$. iliotibials lateralis and $m$. iliotibialis cranialis from thigh were measured. The morphometric study of the selected parameters was performed by using scale ( $\mathrm{cm}$ and $\mathrm{mm}$ ) and electric balance.

\section{RESULT AND DISCUSSION}

Morphometry of muscles

In the present study skeletal muscles of various regions of the body of Cobb-500 and Ross broiler strains were found to differ in length, breadth, thickness and weight. Pectoralis superficialis muscle from the breast of Cobb-500 was higher in length $(153.60 \pm 0.67 \mathrm{~mm})$, breadth $(53.00 \pm 0.70 \mathrm{~mm})$, thickness $(15.00 \pm 0.70 \mathrm{~mm})$ and weight $(73.58 \pm 0.66 \mathrm{gm}$ ) in comparison to those Ross strain (length $148.00 \pm 0.70 \mathrm{~mm}$, breadth $49.00 \pm 0.70 \mathrm{~mm}$, thickness $13.60 \pm 0.74 \mathrm{~mm}$, weight $68.60 \pm 0.72 \mathrm{gm}$ ) at 35 days of age. In the thigh Iliotibialis lateralis was also higher in Cobb-500 in comparison to those of Ross strain. So, the same muscle of the same region was highest in length, breadth, thickness and weight in Cobb-500 in comparison to that of Ross broiler strains (Table 1).

Table 1. Length, breadth, thickness and weight (mean \pm SE) of the muscles of breast and thigh region of Cobb500 and Ross broiler chickens at $1^{\text {st }}, 7^{\text {th }}, 14^{\text {th }}, 21^{\text {st }}, 28^{\text {th }}$ and $35^{\text {th }}$ days of age $(n=5)$

\begin{tabular}{|c|c|c|c|c|c|c|c|c|}
\hline \multirow[t]{2}{*}{ Name of muscles } & \multicolumn{4}{|l|}{ Cobb-500 } & \multicolumn{4}{|l|}{ Ross } \\
\hline & $\begin{array}{l}\text { Length } \\
(\mathrm{mm})\end{array}$ & $\begin{array}{l}\text { Breadth } \\
(\mathrm{mm})\end{array}$ & $\begin{array}{l}\text { Thicknes } \\
\mathrm{s}(\mathrm{mm})\end{array}$ & $\begin{array}{l}\text { Weight } \\
(\mathrm{g})\end{array}$ & $\begin{array}{l}\text { Length } \\
(\mathrm{mm})\end{array}$ & $\begin{array}{l}\text { Breadth } \\
(\mathrm{mm})\end{array}$ & $\begin{array}{l}\text { Thicknes } \\
\mathrm{s}(\mathrm{mm})\end{array}$ & $\begin{array}{l}\text { Weight } \\
(\mathrm{g})\end{array}$ \\
\hline \multicolumn{9}{|l|}{ Age: 1 day } \\
\hline $\begin{array}{l}\text { Pectoralis } \\
\text { thoracis }\end{array}$ & $38.0 \pm 0.3$ & $14.0 \pm 0.6$ & $1.0 \pm 0.07$ & $\begin{array}{l}0.17 \pm 0.0 \\
1\end{array}$ & $35.6 \pm 0.31$ & $12.5 \pm 0.2$ & $0.7 \pm 0.04$ & $0.1 \pm 0.04$ \\
\hline Supracoracoideus & $31 \pm 0.17$ & $9.0 \pm 0.18$ & $0.5 \pm 0.04$ & $0.7 \pm 0.04$ & $28.0 \pm 0.24$ & $7.9 \pm 0.16$ & $0.3 \pm 0.04$ & $0.5 \pm 0.05$ \\
\hline Iliotibialis & $31.3 \pm 0.1$ & $12.0 \pm 0.1$ & $0.9 \pm 0.04$ & $0.17 \pm 0.0$ & $27.9 \pm 0.15$ & $11.7 \pm 0.1$ & $0.9 \pm 0.04$ & $0.17 \pm 0.0$ \\
\hline lateralis & 8 & & & 3 & & 9 & & 3 \\
\hline $\begin{array}{l}\text { Iliotibialis } \\
\text { cranialis }\end{array}$ & $26.0 \pm 0.1$ & $4.1 \pm 0.14$ & $1.3 \pm 0.04$ & $0.1 \pm 0.04$ & $24.7 \pm 0.17$ & $4.5 \pm 0.19$ & $1.3 \pm 0.02$ & $0.1 \pm 0.02$ \\
\hline \multicolumn{9}{|l|}{ Age: 7 days } \\
\hline $\begin{array}{l}\text { Pectoralis } \\
\text { thoracis }\end{array}$ & $51.4 \pm 0.6$ & $21.6 \pm 0.4$ & $3.0 \pm 0.09$ & $1.7 \pm 0.03$ & $52.2 \pm 0.25$ & $20.0 \pm 0.5$ & $3.4 \pm 0.09$ & $1.6 \pm 0.02$ \\
\hline Supracoracoideus & $42.6 \pm 0.4$ & $11.0 \pm 0.2$ & $1.9 \pm 0.06$ & $0.4 \pm 0.04$ & $42.5 \pm 0.29$ & $11.0 \pm 0.1$ & $2.0 \pm 0.05$ & $0.4 \pm 0.01$ \\
\hline $\begin{array}{l}\text { Iliotibialis } \\
\text { lateralis }\end{array}$ & $41.7 \pm 0.5$ & $19.0 \pm 0.1$ & $2.0 \pm 0.07$ & $0.6 \pm 0.02$ & $40.8 \pm 0.37$ & $18.3 \pm 0.3$ & $2.0 \pm 0.07$ & $0.5 \pm 0.01$ \\
\hline Iliotibialis & $35.0 \pm 0.3$ & $8.0 \pm 0.16$ & $2.0 \pm 0.07$ & $0.3 \pm 0.02$ & $34.0 \pm 0.35$ & $7.0 \pm 0.16$ & $2.0 \pm 0.07$ & $0.2 \pm 0.13$ \\
\hline cranialis & \multirow{2}{*}{\multicolumn{8}{|c|}{ Morphological analysis of breast and thigh muscles of broiler chicken }} \\
\hline Age: 14 days & & & & & & & & \\
\hline $\begin{array}{l}\text { Pectoralis } \\
\text { thoracis }\end{array}$ & $76.0 \pm 0.1$ & $32.0 \pm 0.3$ & $5.0 \pm 0.16$ & $6.6 \pm 0.07$ & $76.0 \pm 0.06$ & $33.0 \pm 0.2$ & $5.0 \pm 0.16$ & $6.7 \pm 0.02$ \\
\hline Supracoracoideus & $61.2 \pm 0.2$ & $22.0 \pm 0.1$ & $2.0 \pm 0.07$ & $3.8 \pm 0.01$ & $62.0 \pm 0.16$ & $23.0 \pm 0.1$ & $2.0 \pm 0.07$ & $3.9 \pm 0.06$ \\
\hline $\begin{array}{l}\text { Iliotibialis } \\
\text { lateralis }\end{array}$ & $51.2 \pm 0.3$ & $23.0 \pm 0.3$ & $2.5 \pm 0.03$ & $1.2 \pm 0.01$ & $51.8 \pm 0.25$ & $23.9 \pm 0.3$ & $2.5 \pm 0.05$ & $1.3 \pm 0.01$ \\
\hline
\end{tabular}




\begin{tabular}{|c|c|c|c|c|c|c|c|c|}
\hline \multirow[t]{2}{*}{ Name of muscles } & \multicolumn{4}{|l|}{ Cobb-500 } & \multicolumn{4}{|l|}{ Ross } \\
\hline & $\begin{array}{l}\text { Length } \\
(\mathrm{mm})\end{array}$ & $\begin{array}{l}\text { Breadth } \\
(\mathrm{mm})\end{array}$ & $\begin{array}{l}\text { Thicknes } \\
\mathrm{s}(\mathrm{mm})\end{array}$ & $\begin{array}{l}\text { Weight } \\
\text { (g) }\end{array}$ & $\begin{array}{l}\text { Length } \\
(\mathrm{mm})\end{array}$ & $\begin{array}{l}\text { Breadth } \\
(\mathrm{mm})\end{array}$ & $\begin{array}{l}\text { Thicknes } \\
\mathrm{s}(\mathrm{mm})\end{array}$ & $\begin{array}{l}\text { Weight } \\
(\mathrm{g})\end{array}$ \\
\hline $\begin{array}{l}\text { Iliotibialis } \\
\text { cranialis }\end{array}$ & $47.9 \pm 0.1$ & $11.0 \pm 0.2$ & $2.5 \pm 0.19$ & $0.5 \pm 0.01$ & $48.0 \pm 0.16$ & $12.0 \pm 0.1$ & $2.5 \pm 0.08$ & $0.6 \pm 0.01$ \\
\hline \multicolumn{9}{|l|}{ Age: 21 days } \\
\hline $\begin{array}{l}\text { Pectoralis } \\
\text { thoracis }\end{array}$ & $102 . \pm 0.8$ & $34.2 \pm 0.2$ & $5.6 \pm 0.24$ & $\begin{array}{l}13.2 \pm 0.0 \\
5\end{array}$ & $99.6 \pm 0.57$ & $\begin{array}{l}32.1 \pm 0.1 \\
9\end{array}$ & $5.5 \pm 0.13$ & $\begin{array}{l}11.6 \pm 0 . \\
2\end{array}$ \\
\hline Supracoracoideus & $83 \pm 0.70$ & $22.8 \pm 0.3$ & $5.5 \pm 0.16$ & $5.1 \pm 0.03$ & $81.4 \pm 0.19$ & $21.7 \pm 0.1$ & $5.0 \pm 0.04$ & $\begin{array}{l}4.8 \pm 0.0 \\
5\end{array}$ \\
\hline $\begin{array}{l}\text { Iliotibialis } \\
\text { lateralis }\end{array}$ & $58.8 \pm 0.4$ & $29 \pm 0.50$ & $3 . \pm 0.06$ & $\begin{array}{l}2.90 \pm 0.0 \\
4\end{array}$ & $54.0 \pm 0.32$ & $24.9 \pm 0.5$ & $2.8 \pm 0.07$ & $\begin{array}{l}2.1 \pm 0.0 \\
3\end{array}$ \\
\hline $\begin{array}{l}\text { Iliotibialis } \\
\text { cranialis }\end{array}$ & $54.3 \pm 0.37$ & $14.6 \pm 0.4$ & $3.2 \pm 0.06$ & $1.6 \pm 0.01$ & $49.1 \pm 0.43$ & $11.2 \pm 0.2$ & $3.1 \pm 0.09$ & $\begin{array}{l}1.2 \pm 0.0 \\
7\end{array}$ \\
\hline \multicolumn{9}{|l|}{ Age: 28 days } \\
\hline $\begin{array}{l}\text { Pectoralis } \\
\text { thoracis }\end{array}$ & $117 . \pm 0.5$ & $44.0 \pm 0.4$ & $10.4 \pm 0.4$ & $35.5 \pm 0.3$ & $114.1 \pm 0.3$ & $41.1 \pm 0.5$ & $9.5 \pm 0.09$ & $\begin{array}{l}32.4 \pm 0 \\
.1\end{array}$ \\
\hline Supracoracoideus & $105 . \pm 0.6$ & $28.8 \pm 2.4$ & $9 \pm 0.17$ & $\begin{array}{l}19.8 \pm 0.0 \\
5\end{array}$ & $102.1 \pm 0.6$ & $27.2 \pm 0.6$ & $8.5 \pm 0.17$ & $\begin{array}{l}17.0 \pm 0 \\
.3\end{array}$ \\
\hline $\begin{array}{l}\text { Iliotibialis } \\
\text { lateralis }\end{array}$ & $67.2 \pm 0.6$ & $33.8 \pm 0.3$ & $3.2 \pm 0.08$ & $6.2 \pm 0.07$ & $62.9 \pm 0.24$ & $\begin{array}{l}32.0 \pm 0.2 \\
8\end{array}$ & $3.1 \pm 0.13$ & $\begin{array}{l}6.1 \pm 0 . \\
12\end{array}$ \\
\hline $\begin{array}{l}\text { Iliotibialis } \\
\text { cranialis }\end{array}$ & $64 \pm 0.57$ & $16.1 \pm 0.6$ & $3.0 \pm 0.21$ & $3.4 \pm 0.23$ & $58.0 \pm 0.57$ & $13 \pm 0.35$ & $2.70 \pm 0.1$ & $\begin{array}{l}3.22 \pm 0 \\
.1\end{array}$ \\
\hline \multicolumn{9}{|l|}{ Age: 35 days } \\
\hline $\begin{array}{l}\text { Pectoralis } \\
\text { thoracis }\end{array}$ & $153.6 \pm 0.6$ & $53 \pm 0.70$ & $15 \pm 0.70$ & $73.5 \pm 0.6$ & $148 \pm 0.70$ & $49 \pm 0.70$ & $13 \pm 0.74$ & $\begin{array}{l}68 \pm 0.7 \\
2\end{array}$ \\
\hline Supracoracoideus & $141 \pm 0.85$ & $42 \pm 0.85$ & $12 \pm 0.85$ & $49.2 \pm 1.4$ & $136 \pm 0.70$ & $38 \pm 0.70$ & $10 \pm 0.67$ & $\begin{array}{l}46.2 \pm 0 \\
.8\end{array}$ \\
\hline $\begin{array}{l}\text { Iliotibialis } \\
\text { lateralis }\end{array}$ & $84 \pm 0.70$ & $40 \pm 0.70$ & $3.5 \pm 0.1$ & $13.4 \pm 0.6$ & $81 \pm 0.70$ & $37 \pm 0.70$ & $3.2 \pm 0.10$ & $\begin{array}{l}11.5 \pm 0 \\
.9\end{array}$ \\
\hline $\begin{array}{l}\text { Iliotibialis } \\
\text { cranialis }\end{array}$ & $78 \pm 0.70$ & $25 \pm 0.70$ & $3.1 \pm 0.11$ & $6.7 \pm 0.6$ & $73 \pm 0.70$ & $21 \pm 0.70$ & $3 \pm 0.11$ & $\begin{array}{l}5.8 \pm 0 . \\
68\end{array}$ \\
\hline
\end{tabular}

\section{Carcass characteristics}

In the present study the higher value of carcass was found in Cobb-500 at different studied postnatal ages in comparison to that of Ross strain (Table 2) and on the basis of this result Cobb-500 may be recommended for farming. The highest dressing percentage (DP) based on live weight was $69.29 \pm 0.11$ in case of Cobb-500 and $69.12 \pm 0.12$ in case of Ross strain at 35 day of age. The differences in dressing percentages in between Cobb-500 and Ross broiler chicken were found statistically non significant $(\mathrm{P}<0.01)$ at $21^{\text {st }}, 28^{\text {th }}$ and $35^{\text {th }}$ day of age whereas at day old, $7^{\text {th }}$ and $14^{\text {th }}$ day the differences were significant (Table 2). The average weight of major edible cut portions like breast, thighs, and drumsticks were higher in Cobb-500 in comparison to those of Ross broiler strain and these differences become more significant with the advancement of age (Fig. 1-3). The breast yield at $35^{\text {th }}$ day of age of Cobb-500 (432.03 $\left.\pm 3.27 \mathrm{~g}\right)$ was in agreement with Nicolova et al. (2009) who recorded $430.71 \mathrm{~g}$ breast at $35^{\text {th }}$ day of age in Cobb-500. Teuśan et al., (2009) reported 22-25\% breast musculature in Cobb-500 and it was calculated as $29.51 \%$ at $35^{\text {th }}$ day of age in the present study. In the present study the result of thigh $(13.07 \%)$ and drumstick $(13.85 \%)$ yield of Cobb-500 at the age of $35^{\text {th }}$ day were higher than that of Nicolova et al. (2009) who concluded $9.59 \%$ thighs and $10.32 \%$ drumsticks in Cobb-500 at $35^{\text {th }}$ day of age. The drumsticks yield in Ross strain at $35^{\text {th }}$ day of age was $13.51 \%$ which was lower than that of Ojedapo et al. (2008) (17.94\%). The present study was also in accordance with result from Santos et al. (2004) and Marcato et al. (2006) researches who concluded significantly larger breasts and drumsticks in chicken of Cobb-500 genotype than in other genotypes. Nicolova et al. (2009) noted that age of slaughtering has effect on most of carcass parts of commercial chickens that has been proved in the present study. The lean: bone ratio has an important impact 


\section{S. Rahman}

on meat quality. In the present study the total lean and bone were determined separately at every studied age. Total lean and bone production was higher in Cobb-500 but lean: bone ratio was higher in Ross strain (Table 2) at every studied age except $21^{\text {st }}$ day of age.

Table 2. Live weight and carcass characteristics of Cobb-500 and Ross broiler chickens at $1^{\text {st }}, 7^{\text {th }}, 14^{\text {th }}, 21^{\text {st }}, 28^{\text {th }}$ and $35^{\text {th }}$ days of age $(n=5)$

\begin{tabular}{|c|c|c|c|c|c|c|}
\hline \multirow{2}{*}{$\begin{array}{l}\text { Parameters } \\
\text { and Strains }\end{array}$} & \multicolumn{6}{|c|}{ Age } \\
\hline & Day-1 & Day-7 & Day-14 & Day-21 & Day-28 & Day-35 \\
\hline \multicolumn{7}{|c|}{ Live Weight (g) } \\
\hline Cobb-500 & $47.31 \pm 1.93$ & $93.18 \pm 0.56$ & $199.94 \pm 1.56$ & $470.60 \pm 2.42$ & $1066.46 \pm 1.04$ & $1860.18 \pm 6.29$ \\
\hline Ross & $42.49 \pm 0.64$ & $91.61 \pm 0.36$ & $197.50 \pm 0.64$ & $467.14 \pm 2.80$ & $987.40 \pm 2.09$ & $1640.47 \pm 7.57$ \\
\hline \multicolumn{7}{|c|}{ Hot carcass Weight $^{\mathrm{a}}(\mathrm{g})$} \\
\hline Cobb-500 & $14.90 \pm 0.53$ & $27.85 \pm 0.30$ & $85.31 \pm 0.82$ & $211.94 \pm 4.31$ & $618.36 \pm 0.92$ & $1289.05 \pm 5.39$ \\
\hline Ross & $12.89 \pm 0.41$ & $25.83 \pm 0.38$ & $82.09 \pm 0.35$ & $210.58 \pm 2.66$ & $565.55 \pm 2.41$ & $1133.80 \pm 3.51$ \\
\hline \multicolumn{7}{|c|}{ Dressing Percentage $^{b}$} \\
\hline Cobb-500 & $31.57 \pm 0.94$ & $29.63 \pm 0.19$ & $42.65 \pm 0.11$ & $45.01 \pm 0.69$ & $57.97 \pm 0.05$ & $69.29 \pm 0.11$ \\
\hline Ross & $30.31 \pm 0.53$ & $28.18 \pm 0.33$ & $41.56 \pm 0.09$ & $45.07 \pm 0.29$ & $57.27 \pm 0.13$ & $69.12 \pm 0.12$ \\
\hline \multicolumn{7}{|c|}{ Total Lean Weight (g) } \\
\hline Cobb-500 & $7.65 \pm 0.02$ & $13.17 \pm 0.02$ & $50.66 \pm 0.26$ & $96.69 \pm 0.38$ & $381.29 \pm 1.56$ & $797.77 \pm 3.20$ \\
\hline Ross & $6.82 \pm 0.05$ & $12.52 \pm 0.06$ & $48.56 \pm 0.28$ & $92.44 \pm 0.78$ & $345.48 \pm 1.60$ & $694.89 \pm 4.80$ \\
\hline \multicolumn{7}{|c|}{ Total Bone Weight（g) } \\
\hline Cobb-500 & $6.58 \pm 0.03$ & $11.82 \pm 0.42$ & $27.29 \pm 0.29$ & $82.58 \pm 0.43$ & $147.71 \pm 1.53$ & $298.84 \pm 3.96$ \\
\hline Ross & $5.83 \pm 0.05$ & $10.44 \pm 0.03$ & $25.69 \pm 0.40$ & $82.44 \pm 2.26$ & $130.33 \pm 1.29$ & $257.53 \pm 4.90$ \\
\hline \multicolumn{7}{|c|}{ Tissue ratio in carcass (ratio of lean and bone) } \\
\hline Cobb-500 & $1.17 \pm 0.01$ & $1.12 \pm 0.04$ & $1.86 \pm 0.01$ & $1.17 \pm 0.002$ & $2.38 \pm 0.21$ & $2.67 \pm 0.02$ \\
\hline Ross & $1.17 \pm 0.01$ & 1. $20 \pm 0.01$ & $1.89 \pm 0.02$ & $1.12 \pm 0.003$ & $2.65 \pm 0.01$ & $2.70 \pm 0.03$ \\
\hline
\end{tabular}

${ }^{\mathrm{a}}$ Reduction of skin, head, organ of thoracic, abdominal, and pelvic cavities from total carcass; ${ }^{b}$ Ratio of hot carcass weight and live body weight

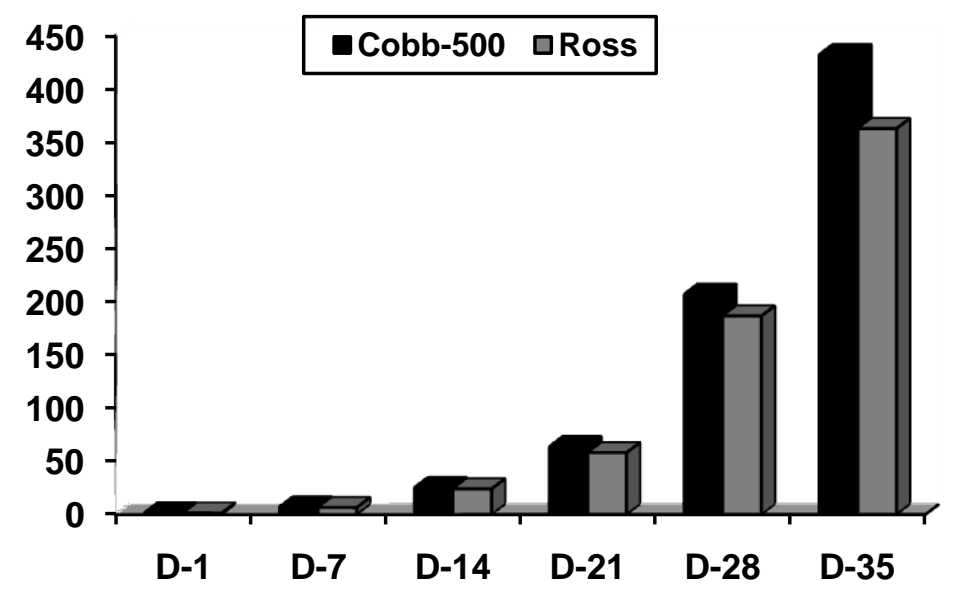

Fig. 1. Growth curve and growth rates of breast yield in Ross and Cobb-500 broiler strains (Values of the X axis indicates the weights $(\mathrm{g})$ and $\mathrm{Y}$ axis indicates the age of the birds) 


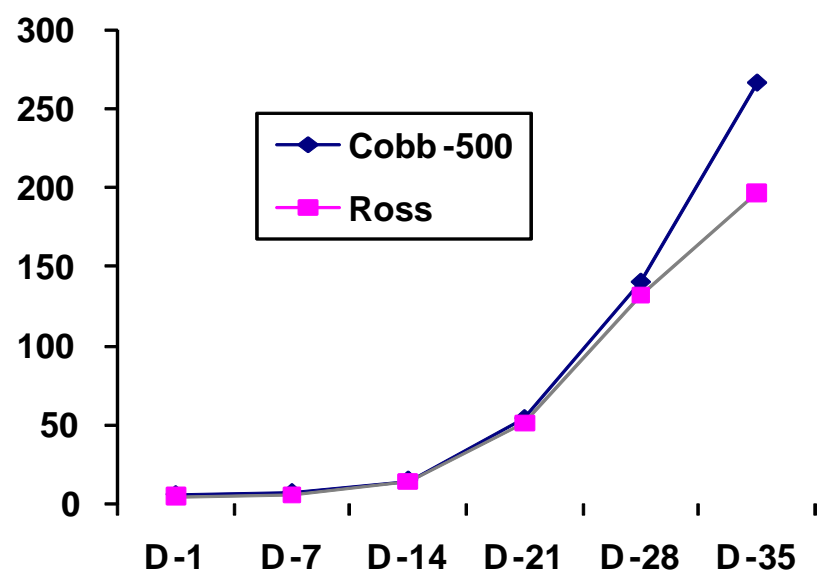

Fig. 2. Growth curve and growth rates of legs meat yield of Ross and Cobb-500 broiler strains (Values of the X axis indicates the weights ( $\mathrm{g}$ ) and $\mathrm{Y}$ axis indicates the age of the birds)

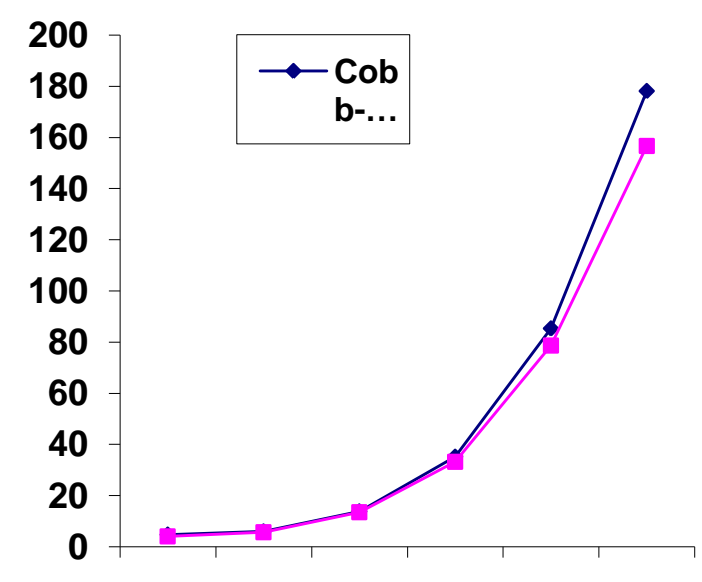

D-1 D-7 D-14 D-21 D-28 D-35

Fig. 3. Growth curve and growth rates of drumstick yield of Ross and Cobb-500 broiler strains (Values of the $\mathrm{X}$ axis indicates the weights $(\mathrm{g})$ and $\mathrm{Y}$ axis indicates the age of the birds)

This study concludes that strain selection and age of the bird are two significant criteria in commercial broiler farming system. Muscular growth and meat yield are very important to evaluate the total production and profitability of the farm. Cobb-500 strain has a higher skeletal muscle growth and meat yield than those of Ross strain. Therefore Cobb-500 may be the first choice for better meat production and profit through broiler farming in Bangladesh.

\section{REFERENCES}

1. Adela Marcu, Văcaru-opriş I, Marcu A, Cornelia Vintilă and Dronca D (2009). The influence of feed protein level on productive performances at Ross 308 hybrid. Lucrări ştiinţifice Zootehnie şi Biotehnologii 42 (1).

2. Huque QME (1996). Improving Skills of the small farmers in poultry management. Poultry Science 35: 412-418.

3. Huque QME and Stem C (1993). Current status of poultry production and marketing systems in Bangladesh. Bangladesh Agricultural research Council/ USAID/ Checchi and Company Consulting Inc. 


\section{S. Rahman}

4. Le Bihan-Duval E, Berri C, Baeza E, Millet N and Beaumont C (2001). Estimation of the genetic parameters of meat characteristics and of their genetic correlations with growth and body composition in an experimental broiler line. Poultry Science 80: 839-843.

5. Marcato SM, Sakomura NK, Kawauchi IM, Barbosa NAA and Freitas EC (2006). Growth of body parts of two broiler chicken strain. XII European Poultry Conference, September 10-14, Verona, Italy, p. 270.

6. Nikolova N and Pavlovski Z (2009). Major carcass parts of broiler chicken from different genotype, sex, age and nutrition system. Biotechnology in animal husbandry 25 (5-6): 1045-1054.

7. Ojedapo LO, Akinokun O, Adedeji TA, Olayeni TB, Ameen SA and Amao SR (2008). Effect of strain and sex on carcass characteristics of three commercial broilers readed in deep litter system in the derived savannah area of Nigeria. World Journal of Agricultural Sciences 4 (4): 487-491.

8. Santos AL, Sakomura ER, Freitas ER, Barbosa NAA, Mendonca MO and Carrilho ENVM (2004). Carcass yield and meat quality of three strains of broiler chicken. XXII World poultry congress, WPSA Turkish Branch, Jun 8-13, Istanbul, Turkey.

9. Teuşan V, Radu-Rusu RM and Teusan A (2009). Investigations on the histological structure of the superficial pectoral muscle in Cobb-500 commercial meat-type hybrid hen. Cercetări Agronomice in Moldova, Vol, XLII, No. $4(140) / 2009$.

10. The International Food Policy Research Institute (IFPRI, 2000).

11. Wats G and Kennet C (1995). The broiler industry. Poultry tribune 7 (Sep): 6-18.

12. Young LL, Northcutt JK, Buhr RJ, Lyon CE and Wane GO (2001). Effects of age, sex and duration of postmortem aging on percentages yield of parts from broiler chicken carcasses. Poultry Science 80: 376-379. 